\title{
Youths Involvement in Self-Help Community Development Projects (SHCDPs) in Nsukka, Enugu State, Nigeria
}

\author{
Mbagwu, F. O. ${ }^{1}$, Mannir, Abba ${ }^{2}$, Ewelum, J. N. ${ }^{3}$ \& Ezema, M. C. ${ }^{1}$ \\ ${ }^{1}$ Department of Adult Education and Extra-Mural Studies, Nigeria \\ ${ }^{2}$ Department of Adult Education and Extension Services, Nigeria \\ ${ }^{3}$ Department of Adult Education, Nnamdi Azikiwe University, Awka, Nigeria \\ Correspondence: Janet Igbo, Department of Educational Foundations, University of Nigeria, Nsukka, Nigeria. Tel: \\ 23-803-746-9921. E-mail: janetigbo@yahoo.com
}

Received: August 12, 2016

Accepted: August 16, $2016 \quad$ Online Published: Nobember 27, 2016

doi:10.5539/res.v8n4p240

URL: http://dx.doi.org/10.5539/res.v8n4p240

\begin{abstract}
In developing countries like Nigeria, every citizen has the right to be involved in any development activities that is targeted at meeting the "felt needs" of their community rather than wait endlessly for government intervention. Self-help community development activities like construction and maintenance of community roads and rural electrification among others, are expected to be facilitated by all the stakeholders in the community, including the youths who are legitimately the future custodian of the welfare of their community and the greatest investment that can be utilized to mobilize local material resources for the community as well as the country's development. This study therefore poses that, if youths are recognized as clear assets in self-help community development projects, the youths with their wealth of experiences and energy can be engaged effectively in meaningful tasks for the improvement of their environment. Thus, the issue of youth migration or abandonment of projects can also be ameliorated. Quantitative and qualitative data were collected on self-help projects embarked on in the communities studied, areas of youths involvement in self-help projects and the constraints encountered by youths. Findings of the study revealed that the Nsukka communities studied embarked on rural electrification, construction of boreholes and water drainage facilities among others; the areas of youths involvement in self help community projects was low; while youths not given free hands to be involved in SHCPs and parents not allowing their youths to be involved in SHCPs among others, were constraints to youths involvement in self help community projects. Recommendations were made based on the findings of the study.
\end{abstract}

Keywords: youth, involvement, self-help, community development projects

\section{Introduction}

From the earliest period of human history people have enjoyed and shared together the good tidings of nature because of the existence of communities and the social activities engaged by the people for the progress of their community, which is better called Community Development (CD). Community development marks the stage in the life of a community where by members come together to take collective actions in order to generate solutions to their identified problems. Community development in this context can be said to be a self-directional effort of the people by the people and for the people. For Hill (2011), it means a coordinated approach whereby the community members undertake programs and projects in order to better the living condition of the people residing in that community. This according to Johnson (2008) implies the improvement in the physcal and material wellbeing including livelihood of people in the community. Community development therefore, help people to recognize and develop their ability and potential in order to address their problems and needs which they share (Effiong, 2012).

Some scholars like Afuye (2015) posit that community development is a structured intervention that gives communities greater control over the conditions that affect their lives. This however, does not solve all the problems faced by a local community, but it does build up confidence to tackle such problems as effectively as any local action can perform. In essence, community development works at the level of local groups and organizations rather than with individuals or families. Implying that community development has to look both ways; not only at how the community is working at the grassroots, but also how responsive key institutions are to the needs of local communities. Community development however, appears in different forms in different countries regardless of 
their level of development but they uphold the same basic principles of people's involvement in bringing about better socio-economic and political conditions of the people; irrespective of their cultural differences.

In Nigeria, community development is not new either. Oduaran (1994), Tolu and Abe (2011) observed that before the advent of colonial administration, various communities designed development-oriented activities on their own in order to improve their standard of living. The spirit of self help which forms the present day strategy for community development guided the zeal of the people as they harnessed their local resources and undertook community development projects like building of markets, community halls, road expansion and maintenance, tree planting to check erosion and communal palm fruits harvesting, amongst others. Hence, CD could be regarded as a skilled process which hinges on the approach that controls and uses assets to promote social justice and improves the quality of community life.

From the foregoing, self-help community development projects in Nigeria are basically an attempt to address the "felt needs" of the masses by the people and for themselves. According to Oduaran (1994), self-help community projects are those tangible ventures that the inhabitants of the community embark on, in order to improve the conditions of people residing in that community. For example, Anyanwu (2010) noted that in some south-east Igbo speaking communities, part of the money realized from sale of communal palm fruit harvested was used to sponsor the education of indigent students in the community as well as execute other small and medium scale development projects spanning across a variety of fields such as improving health care delivery services, agriculture, nutrition, communal road maintenance, sanitation and rural cooperative thrift services. One of the basic assumptions of community development herein is that community development activities are all inclusive as it provides opportunity for people to learn and grow thus, ensuring that no segment of the populace is exempted, youths inclusive.

The youths in question can be conceptualized as a people within the age bracket of 13 and 24 years (Liveright, 2013), 15 and 24 (UNESCO, https://www.unesco.org-21-5-15), but varies around the world (UN, 2008). For example in Nigeria youths are limited to the ages between 16 and 35 years, whereas in Cameroun it is a period between the age of 14 and 25. Youth is a period of transition from being dependent to construction of self concept, being influenced by peers, life style and gender. Youths constitute the most active labor force of every community. There are about 1.2 billion youths between the age bracket of 15 and 24 years old in the world and about one billion live in developing countries (World Bank Report, 2010). Similarly, National Bureau Statistics Youth Survey Report (2012) showed that nearly 50\% of developing world population are youths within the age bracket of 15 and 35. This is often referred to as the youth bulge, since young people constitute a high proportion of many country's population as evidenced in Nigeria with a population over 174,507,539 million people out of which 64 million are youths with about 54\% of them unemployed (Nigeria National Baseline Youth Survey, 2015).

This increase in youth population represents both a challenge and a responsibility to the society, as majority of them may not have any source of income and livelihood. It is visibly noticed in the society today that the lingering effect of youth bulge creates un-conducive atmosphere in various communities with most of them being idle, unemployed and displaying unruly behaviors (Rowland, 2011). Definitely, being young is a transitional phase of life which carries with it increased vulnerabilities and delinquencies. If the youths are not adequately harnessed it becomes a problem. Youths therefore, could be effectively mobilized and involved as assets, beneficiaries, partners and youth leaders in community development activities which abound in various communities; instead of displaying their unruly behaviors as militants, terrorists and other restiveness in the community and society today.

lnvolvement is the act of participating in the achievement or accomplishment of a particular task. Youths involvement in the context of this study means giving the youths opportunity to effectively participate as facilitators in community development agenda in all the stages because of the effect it will have on their lives now and in future. Through their involvement they will be acquainted with the myriad of problems in their communities and suggest remediation. It is worth mentioning that historically, youths have played a very prominent role in the continual process of governance. They are also responsible for the various changes as witnessed in the history of various nations. Youths generally are daring, full of energy and vigor, inquisitive, enterprising, exuberant, self-sacrificing, full of dreams, beautiful initiatives and hopes. All these attributes of youths can be used to boost community development projects. There is a strong belief that their effective involvement in self-help community development projects by community leaders is desirable in our quest for the qualitative development of our rural communities especially in these days of continued cutbacks in the votes for development by the government at all level. It could also, to a great extent make the youths become responsible and realize that they also have a commitment to themselves, to their communities and nation at large. 
Interestingly, participation in community development of the entire population and all individuals including youths was the theme of the 1986 United Nation Declaration on the Right to Development which was first recognized in 1981, in article 22 of the African Charter on Human and Peoples' Rights; that everybody shall have the right to their economic, social and cultural development with due regard to their freedom and identity ..., and subsequently proclaimed by the United Nations in 1986 as a group right of people which was reaffirmed by the 1993 Vienna Declaration and Program of Action. Hence, a right-based approach to youths involvement in community development has been advocated and widely adopted by many countries and bilateral donor agencies. Understandably, development involves the participation of all (irrespective of age, sex or status) directly and indirectly without any individual or groups being isolated.

Literature showed that in most developing countries, community development projects have not been given so much consideration because of the prevalence in social exclusion of youths from the societal plan of action (World Bank, 2010). The social exclusion of majority of youths in community development activities is prevalent in the developing parts of the world including Africa and Asia. Little wonder, there is currently a shift in working with young people towards positive direction and valuing them as assets, advisors, colleagues and perhaps leaders. In development parlance, such leaders in the community are regarded as change agents. Abiona (2012) noted that community leaders are agents of change that motivate and mobilize community members to improve their standard of living. Hence, youths can also be involved in facilitating progress of their communities through their youth groups, right from the goal setting, problem solving and goal achievement. That means involving them from the planning stage through executing, influencing, directing, supervising, coordinating and evaluating development activities.

However, Hermsillo (2012) argued that when working with youths, it is also vital to consider and acknowledge the decision-making dynamics of any given situation, because young people are often in a situation where decisions are being made for them and exerted over them by older adults and this scenario is pathetic. Understanding the dynamics of youths in every local context is therefore essential for effective community development activities. This is because each generation of youths certainly would exhibit their own characteristics and may face different challenges that would also require its own peculiar solution approach. No wonder Kelly (2008), Olufemi (2014) noted that in most developing countries of the world, the youths have not been properly integrated into community development activities of their various governments and communities. According to Olufemi, it has always been a common belief among most people in developing countries like Nigeria, that every development issue is the sole responsibility of the government and perhaps their agencies, to provide infrastructural and physical facilities as well as social amenities. Considering the obvious economic crisis in Nigeria, it may not be possible that government budget capacity can accommodate the magnitude of development challenges in the country. Consequently, communities seem to be on the right track to improving their welfare facilities through self help development activities.

Onah (2013) is concerned about the various institutions including schools that exist in developing countries that are not helping matters too, as many youths are continually being excluded from community development activities. The writer noted with dismay that the exclusion of youths from development activities at community or even national levels has negatively affected their contribution towards so many development projects that abound in various communities. This may be true as evidenced from pilot study of communities in Nsukka Local Government Area of Enugu State Nigeria, under study, where there are visible abandoned self-help community development projects, such as community self help rural electrification project, massive erosion sites without appropriate drainage, chain pot holes and bore-hole water projects among others. Perhaps, if the youths were given free hand and effectively involved, they could have provided at least remediation for the chain pot holes and drainage system. Youths are recognized as the key human resources required for helping most communities meet the new challenges of their environment as well as their subsistence needs and in doing so, improve local people's long-term security and control over their own lives (Zeldin, 2012). Generally, they are equipped with indigenous knowledge, skills and resources that can be utilized in making sure that community self-help projects do not die a natural death or abandoned. In fact, their involvement is very essential for any community that is aspiring for massive development (Sieng, 2012). Youths can be important facilitators of community development projects because they are innovative, inquisitive, creative in problem solving and solution finding, have enduring interest during discussions and continuous dialogue during ongoing projects in order to forestall anomalies at the early stage, which if not rectified will cause irreparable damage to the projects.

Considering the fact that community development has a wide variety of activity, it is expected that effective involvement of all beneficiaries in the activities gives them the opportunity to learn how to develop their potentials or talents and acquire more relevant skills that would help them to grow and contribute meaningfully to their 
community and society at large. However, another critical factor that may impede youth involvement in community development in developing countries like Nigeria, is that majority of the youths are still dependent on their parents for the provision of basic needs which include: education, food, shelter and clothing and as such do not assume responsibilities till they even get married. In situations like this, it could be perceived that most youths may be non challant, passive and even decline in community development activities because they lacked ideas on what to do and would not be taken seriously for any responsibility. In a contrasting view Adefemi (2008) reiterated that youths generally, are capable and known to have so much energy to expend in the implementation, facilitating, monitoring, supervision, and evaluation of community development projects and as such, it is imperative to re-position the youths by engaging them effectively in meaningful development activities in their various localities instead of their being liability to the community and self-help projects being paralyzed or abandoned; when the youths would have been utilized in executing such development projects. Although one begins to ponder on why many projects meant for the people's own welfare are abandoned. Anyanwu (2010) submits that most abandoned community projects are attributed to lack of political will, poor planning, implementation, inadequate funding, monitoring, supervision and formative evaluation of the projects; whereas the youths would be very useful in this regard because of their wealth of knowledge, technology and energy they can expend in performing developmental tasks. Smith (2010) also argued that youths are a heterogeneous group with wealth of life experiences, cultural background, education and social group affiliation that can make positive impacts in the community depending on where they live. Therefore, considering the dividends that may accrue to various communities if the youths are adequately involved and utilized in community development projects, it would to a very great extent help to reduce further abandonment of projects and also help to curb rural-urban drift of youths and various social ills in rural communities and the society.

Hence, the need for this study which seeks to examine the involvement of youths in community Development Projects. Any attempt to examine their involvement must require the gathering of information using various methods to systematically assess the effectiveness and efficiency of the subject being investigated. Assessment according to Maxwell (2013) is the coordinated process of evaluating, investigating and examining a given phenomenon in order to ascertain useful information and feedback that will be used to address pertinent problems about the phenomenon. Thus, this study will provide information on the self-help community development projects embarked upon by communities in the study areas, ascertain the areas of youths involvement in self-help community development projects and finally find out the constraints to youths involvement in self-help community development projects in Nsukka Local Government Area of Enugu State.

\subsection{Statement of the Problem}

Most communities in developing countries like Nigeria are known for embarking on self-help development projects but the sad irony is that they hardly complete most of these projects. Consequently, it appears that their efforts are not commensurate with all they have invested. Evidence from the pilot study by the researcher's in the study area, showed some abandoned self-help projects. It seems not possible to even ascertain the areas and level of involvement of all stakeholders in the communities especially the youths who are supposed to fast track development activities in their communities. Although, literature showed that community development officers and experts especially in developing countries, like Nigeria, have frowned at the low involvement of youths in community development. So many reasons have been adduced for such anomaly, which include; that youths seem not to be considered as matured people and as such have been excluded right from decision making process, planning, implementation, supervision and evaluation of community development projects by community development stakeholders. The stakeholders in question include all parents, community leaders in the community. In some rare occasion, when the youths willingly participated in community development activities, they seem not to be given a free hand to participate in vital issues like, decision making process, project implementation, supervision and evaluation. Could it be that community leaders and other stakeholders are not convinced that if the youths are effectively involved in their own community development projects, it would to a great extent reduce abandonment of self-help projects, make significant impact on the lives of the people now and in future, as well as help to curb various social ills which has eaten very deep like cankerworms into the fabrics of societies world over. Hence, the essence of this study which focused on examining youths' involvement in self-help community development projects in Nsukka local government area of Enugu State.

\subsection{Review of Materials Related to This Study}

Ezenyem (2012) carried out a study titled "Families Involvement in Self-help Community Projects for Sustainable Development: A Case Study of Amadunu Community in Nnobi Idemili South Local Government Area of Anambra State". The population of the study consisted of 200 respondents. Questionnaire was used for data collection, while simple percentage was used to analyze the data collected. Some of the major findings were that: 
the people of Amadunu community participated actively in community development efforts as could be seen from the various projects they embarked upon and which some were completed, while others were nearing completion. Ezenyem's study is related to this present study because both emphasized on self-help community development but vary in the aspect that the former centered on families involvement in self-help projects while the later focused on youths involvement in self-help community development projects.

Nwankwo (2008) carried out a study titled "Factors Militating against the Involvement of Women in Community Development Projects in Oyi Local Government Area of Anambra State". The population for the study consisted of 600 registered members of women organizations in the local government. The researcher used simple random sampling technique to determine the sample size of 300 respondents for the study. A 20 -item questionnaire was the instrument used to elicit information from the respondents. The data were analyzed using mean and standard deviation. The findings revealed that illiteracy among majority of the women and inadequate mobilization were major factors that affected the women's involvement in community development projects in Oyi Local Government Area of Anambra state. The study is related to this present study because both studies focused on involvement of youths and women in community development projects but differed from the former which examined only the factors militating against the involvement of women in community development projects while the present study was centered on ascertaining the projects embarked upon, areas of youths involvement in community development projects and the constraints.

Finally, Anderson (2005) carried out a study to determine the level of youth's participation in community development projects in Lima town in the South American country of Peru. The study adopted a descriptive survey research design. The population for the study was 150 youths purposively selected from 305 youths in five localities. There was no sampling because the population was a manageable size. Using a one way analysis of variance (ANOVA) to analyze the data, it was revealed that a small percentage of $31.5 \%$ or 71 youths involved voluntarily in community development projects in Lima, while majority $68.7 \%$ of youths, because of their illiteracy and poverty, exhibited a laissez faire attitude towards the development of their community. Both studies are related in scope but differed in the analytical tool used and the area of study.

\subsection{Purpose of the Study}

The general purpose of the study was to examine youth involvement in self-help community development projects in Nsukka Local Government Area (LGA), Enugu State. Specifically, the study sought to:

(1) Ascertain self-help community development projects embarked upon by communities in Nsukka, LGA, Enugu, State.

(2) Ascertain the areas of youth's involvement in self help community development projects.

(3) Determine the constraints to youth's involvement in self-help community development projects in Nsukka, LGA.

\subsection{Research Questions}

The following research questions guided the study:

(1) What are the self-help community development projects embarked upon by communities in Nsukka, LGA of Enugu State?

(2) What are the areas of youth's involvement in self-help community development project in Nsukka, LGA of Enugu State?

(3) What are the constraints to youth's involvement in self-help community development projects in Nsukka LGA of Enugu State?

\subsection{Hypotheses}

The following null hypotheses were formulated for the study and tested at 0.05 level of significance.

$\mathrm{HO}_{1}$ : There will be no significant difference between the mean ratings of male and female youths respondents on the various self-help community development projects embarked upon by communities in Nsukka LGA, Enugu state.

$\mathrm{HO}_{2}$ : There will be no significant difference between the mean ratings of community leaders and youths on the constraints to youth's involvement in self-help community development projects in Nsukka LGA, Enugu state. 


\section{Research Method}

The study adopted descriptive survey research design. Descriptive survey research design according to Nworgu (2015) aims at studying a group of people by collecting and analyzing data from a sample of the same group, considered to be a representative of the entire group. This design is considered appropriate for this study because it helped in eliciting information from the respondents on youth's involvement in self-help community development projects in Nsukka Local Government Area of Enugu State, Nigeria. In addition, a qualitative method of field survey in the form of Focus Group Discussion (FGD) was also used. Trammelan (2010) opined that Focus Group Discussion is a group of discussants that are directed through a well prepared questioning sessions addressing the subject under consideration, with a moderator who guides the group. The FGD provides a two-way communication, offers time for in-depth discussion, provides immediate feedback on new information, promotes group spirit when common concerns are identified and allows for emotional as well as intellectual reactions to responses. Hence, both quantitative and qualitative methods of field survey were used in this study by the researchers. The study was conducted in Nsukka Local Government Area, Enugu state, which is one of the largest in the state. It is made up of twelve towns namely: Nsukka, Obukpa, Opi, Obimo, Alor Uno, Eha-Alumona, Ede-Oballa, Okpuje, Lejja, Edem, Ibagwa-Ani and Okutu. The people of this area have some common characteristics which includes: common beliefs, culture and value system. The area was preferred because of the researchers concern for abandoned projects which could have to a great extent, enhanced the standard of living of the people.

The population of the study was all the 4,012 respondents, comprising 4,004 registered members of community based youths organizations and eight (8) community leaders in the eight (8) out of twelve (12) towns in Nsukka Local Government Area. The sample for the study was 408 respondents comprising 400 males and females youths registered members of community based youth organizations and 8 traditional community leaders (all males). A proportion of $10 \%$ of the population, 4,012 respondents was used as sample size for the study. The choice of $10 \%$ was based on the premise that if the population is in a few thousands a sampling interval of $10 \%$ will do (Nwana, 1991).

Two instruments were used for the study. A 20-item structured questionnaire titled. Youths' Involvement in Community Development Projects Questionnaire (YICDPQ) and a Focus Group Discussion guide (FGD) developed by the researchers. The quantitative research instrument was structured along a four point rating scale of Strongly Agree (SA), Agree (A), Disagree (D) and Strongly Disagree (SD) with numerical values in descending order of 4, 3, 2 and 1.

The Focus Group Discussion (FGD) guide was used to elicit information qualitatively from twelve youths who were randomly selected from four community-based youth organizations not used for the study, but share the same characteristics with the actual subjects. The FGD guide was designed in two parts. Part A was an introductory letter written by the researchers to acquaint the respondents with the purpose of the discussion and thereby solicit their co-operation while given information on issues that was raised during the discussion.

Part B of the FGD was based on the purposes and research questions used for the study. This section was made up of three open-ended questions which the moderator followed diligently. Although other related questions were raised as the need arose.

The two instruments, Questionnaire and Focus Group Discussion guide were given to three experts for validation. Two of the experts were from the department of Adult Education and Extra-Mural studies and one from the department of Science Education Measurement and Evaluation; all in the University of Nigeria, Nsukka. The comments made by the experts were used in modifying the instrument.

The reliability of the instrument was ascertained through a trial test method. Twenty (20) copies of the research instrument were administered on 20 members of five youth organizations in Uzo-Uwani Local Government Area of Enugu State who share the same characteristics with those in the study area but were not used for the study. Cronbach Alpha was used to ascertain the internal consistency of the questionnaire items. The internal consistency reliability coefficient obtained for each of the clusters A, B and C was $0.71,0.73$ and 0.89 respectively. The overall reliability index was 0.78 which was deemed high enough for the study. The research questions were analyzed using mean and standard deviation. The mean benchmark for answering the research questions was 2.5 criterion mean. This means that any item with a mean score of 2.5 and above was accepted while a mean score below 2.5 was unaccepted. T-test statistics was used to test the two hypotheses at 0.05 level of significance. The FGD was transcribed and analyzed qualitatively. 
Table 1. Mean and standard deviation ratings on the self-help community development projects embarked on by communities in Nsukka LGA, Enugu state

\begin{tabular}{|c|c|c|c|c|c|c|}
\hline \multirow[b]{2}{*}{ Items } & \multirow[b]{2}{*}{ Youth $(\mathrm{N}=400)$ Mean } & \multicolumn{5}{|c|}{ Community Leaders $(\mathrm{N}=08)$} \\
\hline & & SD & Decision & Mean & SD & Decision \\
\hline $\begin{array}{l}\text { Involved in Rural electrification } \\
\text { project }\end{array}$ & 3.70 & 0.76 & A & 3.87 & 0.35 & A \\
\hline $\begin{array}{l}\text { Water bore-hole } \\
\text { Project. }\end{array}$ & 3.26 & 0.48 & A & 3.38 & 0.52 & A \\
\hline $\begin{array}{l}\text { Construction of } \\
\text { community market. }\end{array}$ & 3.35 & 0.61 & A & 3.50 & 0.53 & A \\
\hline $\begin{array}{l}\text { Construction of } \\
\text { drainage facilities. }\end{array}$ & 3.35 & 0.48 & A & 3.50 & 0.53 & A \\
\hline $\begin{array}{l}\text { Community school } \\
\text { renovation project. }\end{array}$ & 3.61 & 0.49 & $\mathrm{~A}$ & 3.63 & 0.52 & A \\
\hline $\begin{array}{l}\text { Community } \\
\text { Recreational facility project. }\end{array}$ & 3.49 & 0.50 & A & 3.63 & 0.52 & A \\
\hline $\begin{array}{l}\text { Community health } \\
\text { centre project. }\end{array}$ & 3.63 & 0.48 & $\mathrm{~A}$ & 3.50 & 0.53 & A \\
\hline $\begin{array}{l}\text { Community road } \\
\text { construction project. }\end{array}$ & 3.26 & 0.65 & $\mathrm{~A}$ & 3.00 & 0.76 & A \\
\hline
\end{tabular}

NB: A=Agreed; $\mathrm{SD}=$ Standard Deviation.

Table 1 above presents the various views of youths and community leaders on the self-help community development projects embarked on by communities: From the results, respondents agreed to all the item statements with the corresponding mean scores, ranked from the highest to the lowest: $3.70,3.63,3.61,3.53,3.49$, $3.35,3.26$ and 3.26, for youths and the mean scores in the same descending order for community leaders were 3.87 , $3.63,3.63,3.50 .3 .50,3.50,3.38$ and 3.00 respectively. These mean scores are higher than the criterion mean of 2.5. Implying that both the youths and community leaders agreed that communities in Nsukka LGA embarked on the above named self-help community development projects.

Table 2. Mean and standard deviation ratings showing the areas of youths involvement in self-help community development projects

\begin{tabular}{|c|c|c|c|c|c|c|}
\hline \multirow{2}{*}{ Items } & \multirow{2}{*}{ Youth $(N=400)$ Mean } & \multicolumn{5}{|c|}{ Community Leaders $(\mathrm{N}=08)$} \\
\hline & & SD & Decision & Mean & SD & Decision \\
\hline $\begin{array}{l}\text { They were involved in project planning } \\
\text { process. }\end{array}$ & 1.24 & 043 & $\mathrm{D}$ & 1.13 & 0.35 & $\mathrm{D}$ \\
\hline $\begin{array}{l}\text { Participate in determining the type of facilities } \\
\text { needed for the projects. }\end{array}$ & 1.74 & 0.56 & $\mathrm{D}$ & 1.88 & 0.35 & $\mathrm{D}$ \\
\hline Making suggestions for improvement. & 1.75 & 0.65 & $\mathrm{D}$ & 1.50 & 0.53 & $\mathrm{D}$ \\
\hline Provision of raw materials. & 1.51 & 0.50 & $\mathrm{D}$ & 1.50 & 0.53 & $\mathrm{D}$ \\
\hline $\begin{array}{l}\text { Active supervision of projects so as to achieve } \\
\text { desired project objectives. }\end{array}$ & 1.67 & 0.59 & $\mathrm{D}$ & 1.75 & 0.46 & $\mathrm{D}$ \\
\hline $\begin{array}{l}\text { They were involved in assigning } \\
\text { responsibilities to themselves and keeping } \\
\text { day-to-day records of work, to ensure success } \\
\text { of the project. }\end{array}$ & 1.57 & 0.50 & $\mathrm{D}$ & 1.38 & 0.52 & $\mathrm{D}$ \\
\hline
\end{tabular}

Key: D=Disagree. 
Table 2 above shows the areas of youths involvement in self-help community development projects. The respondents disagreed to all the items as evidenced in the mean scores which are at a lower level than the criterion mean of 2.5. Implying that youths involvement in self-help community development projects was low.

Table 3. Mean and standard deviation ratings showing constraints to youths involvement in self-help community development projects

\begin{tabular}{|c|c|c|c|c|c|c|}
\hline \multirow{2}{*}{ Items } & \multirow{2}{*}{$\bar{X}$} & \multicolumn{5}{|c|}{ Community Leaders $(\mathrm{N}=08)$} \\
\hline & & SD & Decision & Mean & SD & Decision \\
\hline $\begin{array}{l}\text { Youths are not given free hand to be actively } \\
\text { involved in community development projects. }\end{array}$ & 3.59 & 0.68 & A & 3.75 & 0.83 & A \\
\hline $\begin{array}{l}\text { Low educational background of majority of the } \\
\text { youths. }\end{array}$ & 3.43 & 0.64 & A & 3.38 & 0.83 & A \\
\hline $\begin{array}{l}\text { Lack of commitment of some community leaders to } \\
\text { involve the youths leading to out migration of } \\
\text { youths. }\end{array}$ & 3.41 & 0.64 & A & 3.38 & 0.72 & A \\
\hline $\begin{array}{l}\text { Conflict in the community due to corruption and } \\
\text { fund mismanagement. }\end{array}$ & 3.36 & 0.48 & A & 3.25 & 0.69 & A \\
\hline $\begin{array}{l}\text { Parents don't allow their children to be involved in } \\
\text { community development projects. }\end{array}$ & 3.53 & 0.64 & A & 3.50 & 0.76 & A \\
\hline Lack of clear ideas of what the projects has to offer. & 3.38 & 0.52 & A & 3.25 & 0.71 & A \\
\hline
\end{tabular}

Key: A=Agree.

Table 3 above presents the views of the respondents on the constraints to youths involvement in self-help community development projects. From the results both youths and community leaders agreed to all the item statements as the constraints to youth involvement. The mean scores of the groups are greater than the criterion mean of 2.5. Implying that the respondents agreed that the options posed could lead to youths declining from self-help community development projects.

Table 4. T-test analysis of male and female respondents on the self-help community development projects embarked on by communities

\begin{tabular}{cccccccc}
\hline Gender & N(Youths) & Mean & SD & T & Df & sig. & Dec \\
\hline Male & 250 & 3.48 & 0.16 & & & & \\
& & & & 0.477 & 406 & 0.634 & NS \\
Female & 158 & 3.47 & 0.18 & & & & \\
\hline
\end{tabular}

Table 4 above shows that significant value of the Sig 2-tailed test of 0.634 at 406 degree of freedom is greater than 0.05 level of significance; as such the null hypothesis was accepted. Therefore, the null hypothesis which states that there is no significant difference between the mean ratings of male and female respondents on the self-help community development projects was upheld.

Table 5. T-test analysis of Community Leaders (CL) and youths on the constraints to youth's involvement in the self-help community developmen projects

\begin{tabular}{cccccccc}
\hline Gender & N(Youths) & Mean & SD & T & Df & Sig. & Dec \\
\hline Youths & 400 & 3.4471 & .29460 & & & & \\
& & & & .307 & 406 & 0.759 & NS \\
CL & 8 & 3.4792 & .18767 & & & & \\
\hline
\end{tabular}


Table 5 above shows the significance value of the Sig 2-tailed test of .759 at 406 degree of freedom is greater than 0.05 level of significance, as such the null hypothesis was accepted. Therefore, the null hypothesis which states that there is no significant difference between the mean rating of community leaders and youths on the constraints to youth's involvement in self-help community development projects was upheld.

\section{Discussions of the Findings}

Findings revealed that communities in the study area Nsukka indeed, embarked on various self-help community development projects such as rural electrification and community health centre projects among others. The populace may have realized that their destinies lie in their hands and as such change in the community can be promoted through cooperative actions instead of waiting endlessly for the government to provide welfare facilities to them which is seemingly not visible with the prevalent economic crisis in the country. This is in line with Agbo (2012) who affirmed that self help community development implies the improvement in the lives of people, through their own efforts and largely to their own benefits. Corroborating with the author's view, Obetta (2014) noted that no single individual or a segment of the community can provide the felt needs of the people, rather the scenario in CD demands a good endeavor and responsibilities which spells out actions made by community members to bring about better economic, social and political conditions of itself. With regard to the issue of fund mismanagement, it has been recognized as a major cog in the wheel to why most projects are abandoned because it will definitely haze the progress of the projects. This in line with Abubakar (1997) who earlier captured the use of widespread corruption and embezzlement of public fund in Nigeria which is very sad as it has negative consequences on the masses wellbeing, the economy, on-going projects and nation: on development which also has effect community development projects at different levels in different communities.

For findings in the areas of youths involvement in self-help development projects, respondents views were unanimous with mean scores lower than 2.5 criterion mean and low extent options in all the six items. The findings were disheartening but not surprising because the youths perhaps have accepted their fate of not been given a free hand in development issues since they are often viewed as problem than a resource. Changing this perception is important if communities could develop new view points, take a bold step and begin to harness the energy and enthusiasm of youths in their community in order to build a more sustained community. The results were not surprising too as captured by Gardner (1997), Onah (2013) who aptly posit, that youths of today hardly believe that any action on their part towards development initiatives will be recognized in the vast processes of their community or society. Their views may be correct, considering the fact that most adults in the community are not even aware that partnering with youths in an on-going development project, will not only facilitate the projects if other inputs are available; but it will give them an opportunity to bridge some personal gaps, develop a sense of ownership, learn to develop new skills and experiences which will enhance individual's potentials to be able to significantly contribute in meaningful ways. From a different perspective, Mark (2010) noted that youths may only be interested to be involved in community development projects when incentives like money and certificate of merit are provided. However, the author warned that money should not be used as an incentive but as a fair and reasonable benefit for doing a job, elsewhere.

Findings revealed a number of constraints to youth involvement in self-help development projects. Respondents agreed to all the item options as constraints. Evidence from the pilot study conducted by the researchers agrees with the findings especially on the issue of youths not given a free hand to be involved in community development projects. Some youths who were brainstormed by the researchers in the communities studied, testified that they were never carried along because their people felt that they are not matured to be involved in solving community problems. This is in line with Hmosillo (2012) who succinctly observed that most community leaders do not see the need for helping youths to begin their early transition from student to adult member of the community and as such adults make decisions for them and exert them over the youths. Definitely, such perception and social exclusion of youths could lead to conflict in communities. Corroborating with the above view, Gardener (1997), Clerk (2010) lamented at what now seem to be youths exclusion in development, whereas historically in the past, youths willingly assumed responsibilities but in recent decades little is asked of them, as such communities lose their youths to out-migration or all forms of restiveness. Supporting the above view, Obetta (2014) believes that giving the youths opportunity to work with their peers through community initiatives may improve the social inclusion of youths. With regard to youths not having clear ideas of what the projects will offer. Agbo (2012) remarked that youths can become effective contributors in their communities but, like adults they can only do so when they are carried along from the onset and given the opportunity. In fact, they are untapped resources needed to build a more sustained community if they are effectively harnessed.

Also, the findings on the focus group discussions that was transcribed by the researchers revealed a unanimous response from discussants who agreed that their communities embarked upon all the projects listed, such as water 
boreholes and rural electrification among others, even though they had expected that these projects would have been completed, considering their financial involvement in form of levies placed on every adult and their labor. Concerning the areas of youth involvement in self-help community projects, majority testified that in their communities they have limited pool of human resources because the economic situation in the country has compelled the youths to regularly leave them for urban centers in search for greener pasture. An elderly male discussant chipped in that their youths were not sufficiently involved because on many occasions the youths expected remuneration. From then, they became passive because they rarely involved them and yet they complained that they were not carried along. On the issue of what can be done to ameliorate the incidence of abandoned projects, majority stressed on the need for all of them in their communities including their youths to agree on specific periods in the year set aside for embarking on development projects, perhaps everybody will see it as a commitment and their responsibility. While some expressed that they are poor and as such insisted that the government should come and help them out; their source of livelihood is also being threatened. The views of discussants is in line with the submissions earlier made by Umeh and Odum (2011); Iwuchukwu et al. (2015) stated that youths must no longer be relegated to the margins of the community life so that their energetic, resourceful and innovative nature could be felt. In the same line of reasoning, Udensi et al. (2013) earlier remarked that, the development of communities ought to be seen as a dynamic process involving all segments of the locality including youths who are dynamic force for transformation of rural communities. Understandably, the adults alone cannot bring about multifaceted change desired by community members. Therefore, it is suggestive that all entities including youths as well as the government ought to make important contributions to provide communities welfare facilities.

The findings also revealed that there was no significant difference in the mean ratings of male and female youths on self-help development projects embarked on by the communities studied. This implies that the respondents were unanimous in their responses as evidenced in their mean scores which did not differ in all ramifications. All the mean scores were higher than the criterion mean of 2.5, indicating that communities in Nsukka, LGA of Enugu state actually embarked on self-help development projects. This agrees with Johnson (2012), who testified that self-help community projects hinge on the philosophy of people helping themselves and not just waiting for the government to do the job for them. Such community activities enable people to assume their own responsibilities and claim ownership of their community projects as "theirs", even though pilot study revealed that there are abandoned projects in the study area. Finally, the findings of the study revealed that there was no significant difference in the mean constraints scores for youths and community leaders which were higher than the criterion mean of 2.5. This implies that respondents agreed to all the constraints posed; implying that such constraints like; youths are not given free hand, low educational background and parents not allowing their children/youths to be involved in SHCPs among others, can have significant impact on self-help development projects and progress of the community. The low educational background of the youths may also apply to their parents hence, they saw nothing wrong with preventing the youths from being involved in SHCPs. It was unbelievable that youths also lacked clear ideas of what the projects have to offer. If such parents and youths are well educated, perhaps they would appreciate the need to be committed to the development of their communities. This is in line with Ngbea (2013) who affirmed that education is primarily concerned with inculcating worthwhile behavior to individuals to make them become useful to themselves, the community and society at large. Equally Nyerere (1979) succinctly submits that education liberates man from the shackles of ignorance, illiteracy, bondage and poverty. This implies that until these youths and parents' lives are transformed through education, then they will realize that the onus of bringing about change in their communities rests on their shoulders. Therefore, it is believed that in the absence of the constraints revealed in the study, the youths can effectively be harnessed for community development activities, could be more committed and willing to invest their time, energy and talent towards successful execution of development projects in their community.

\section{Conclusion}

The study examined the self-help projects embarked on by the communities studied, the justification for youth involvement in self-help community development projects were discussed, areas of youths involvement and the constraints to their involvement were also examined. Youths have been identified as important segment of the society and inevitable facilitators of community development projects but any misconception about youths by some stakeholders as not matured, being problems instead of viewing them as resources, could lead to low involvement of youths in $\mathrm{CD}$ projects. Constraints to youth involvement in community development projects as revealed in this study include: youths not given free hand to be actively involved in community development projects, low education, parents not allowing their youths to be involved in community development projects, lack of clear ideas of what the projects have to offer and lack of commitment by community leaders to involve the 
youths in community development self-help projects. Such constraints could significantly frustrate communities and their development efforts as well as contribute to abandonment of community projects. However, if communities change their negative perception about youths, they can be harnessed, made to feel free and become more active contributors to solving community problems and also help to build a sustained community. Based on these findings, the researchers made the following recommendations that:

(1) Community development stakeholders should see the youths as an important segment of the populace and future custodian of the community, who should be given opportunity like others, in all aspects of community development efforts such as, in the planning process, implementation, supervision and evaluation of community projects.

(2) Parents should make the education of their youths a top priority so that they can actively be involved in community development activities, as this will contribute immensely to civic engagement of youths than parental modeling.

(3) The elders in the community should cooperate and co-exist in a peaceful and friendly environment with youths who are the prospective elders and leaders of tomorrow.

(4) Government and non-governmental organizations should also assist various communities in their self-help development projects like water borehole project, to enable them improve their standard of living.

\section{References}

Abiona, I. A. (2006). Learning from the animal kingdom: An approach to community mobilization and citizen participation in community development. In Adult Education and Development (pp. 275-282). Journal of the Institute for the Cooperation of German Adult Education Association.

Abubakar, F. U. (1997). The Effect of Corruption in Nigerian Political Terrain. In The Military Experience. Abuja: Apex Publishing Press.

Adefemi, O. (2008). Dimensions and Issues in Community Development Projects. Ibadan Gabesther Education Publishers.

Afuye, H. O. (2005). Community Development in West Africa. Nigeria: Ibadan Publishing Press.

Agbo, E. U. (2012). The Contribution of Co-operative Societies in Capacity Building for Community Development in Igbo-Eze South LGA, Enugu State (Unpublished B.Ed Thesis). Department of Adult Education and Extra-Mural Studies, U.N.N.

Anyanwu, C. N. (2010). Community Development: The Nigerian Perspective. CABESTER Educational Publishers Ibadan.

Clark, I. E. (2010). Community Association: Theory and Practice. Arizona. USA: Mark Gregor Printing Press.

Effiong, J. B. (2012). Evidence from Yakurr L.G.A, Cross River State. International Journal Of Social Science Tommorrow, l(6).

European Union. (1999). An Appraisal of Community Development Projects in Eastern Europe. Oslo, Norway.

Freire, P. (1973). Education for Critical Consciousness. New York: Seabury.

Gardner, J. W. (1997). Leadership Development, Leadership Papers. In Leadership Studies. Programs sponsored by the Independent Sector, Washington D.C.

Hermosillo, L. (2012). Community Leadership. Retrieved June 20, 2015, from http://ucpsarnet. igboprojects.org/communityleadership

Hills, M. (2011). What is Community Development. Retrieved September 8, 2015, from http:www.comdeu.come/authlfan.htm

Iwuchukwu, J. C., Ogbonna, O. I., \& Agbati, I. O. (2015). Roles of Youth Groups in Rural Community development in Ebonyi State, Nigeria. Journal of Agricultural Extension and Rural Development, 7(2), 41-47. http://dx.doi.org/10.5897/JAERD2014.0639

Johnson, K. (2012). Dimensions of Community Development Projects in Guinea. Africana Fep Publishers.

Kelly, W. A. (2008). Constraints to Youths Participation in Community Development. Retrieved August, 2013, from http://www.fening.orgoekamldeve/ikap.htm

Liveright, L. P. (2013). Who is a Youth? Canton Publishing Company, Arizona, USA. 
Mark, P. N (2005). Community Agency and Local Development. University Park: Pennsylvania State University Press.

Maxwell, G. N. (2013). Principles of Evaluation. Washington DC: National Academy Press.

Ngbea, G. T. (2013). The Role of Education in Promoting: A Democratic Society in Nigeria. Makurdi Aboki Publishers.

Nigerian National Baseline Youth Survey. (2015).

Nigerian National Bureau of Statistics Youth Survey Report. (2012). Report on the High Unemployment Rate of Youths in Nigeria.

Nwana, O. (1991). Introduction to Educational Research. Ibadan, Heinemann Education Books.

Nworgu, B. G. (2015). Educational Research, Basic Issues and Methodology. University Trust Publishers Nsukka, Enugu.

Nyerere, J. K. (1979). Education for Liberation and Development. In The Tanzanian Experience (p. 33). London, Evans Brothers Limited.

Obetta, K. C. (2014). Utilization of Community Management Strategy in Community Development Projects in Enugu State, Nigeria (Unpublished Ph.D Thesis). Department of Adult Education and Extra-Mural Studies, U.N.N.

Oduaran, A. B. (1994). An Introduction to Community Development. Benin City Edo State, Nigeria: Uniben Press.

Olufemi, C. (2014). Juvenile Deliquency Among Youths: A Social Malady. Model Publication Limited, Victoria Island, Lagos.

Onah. V. (2013). Contributions of Community Leaders to Community Development in Nsukka Urban (Unpublished B.Ed. Thesis). Department of Adult Education, U.N.N.

Rowland, B. C. (2011). The Meaning of Community Development. New Delhi: Eleventh Conference of the Society for International Development.

Sieng, M. (2012). Community leadership. Retrieved April 20, 2013, from http://ucpsernet.igboproject.org/forununlcommunitybuildingcommunityleadership/communityleadership

Tolu, L., \& Abe, O. (2011). National Development in Nigeria. Issues, Challenges and Prospects.

Trammelan, R. V. (2010). Focus Group Discussion. In An Essential Factor on Project and Programme Evaluation. Oxford University Press.

Udensi, L. O., Daasi, G. L. K., Emah, D. S., \& Zucbec, S. A. (2013). Youth Participation in Community Development Programs in Cross River State, Nigeria. Implications for Sustainable Youth Development in Nigeria. Journal of Humanities Social Science, 13(5), 61-67.

United Nations. (2008). Annual Year book of Statistics.

World Bank. (2010). Community based Monitoring and Evaluation Team.

World Youth Data Sheet. (2010). Population Dynamics of Developing Countries.

Zeldin, S. (2002). From Periphery to Centre: Pathways for Youth Civic Engagement in the Day-to-Day Life of

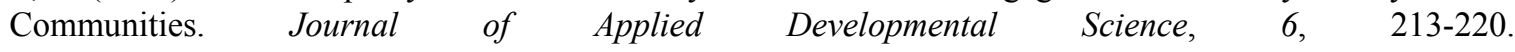
http://dx.doi.org/10.1207/S1532480XADS0604_8

\section{Copyrights}

Copyright for this articleis retained by the author(s), with first publication rights granted to the journal.

This is an open-access article distributed under the terms and conditions of the Creative Commons Attribution license (http://creativecommons.org/licenses/by/4.0/). 